Татјана Брзуловић Станисављевић

Прегледни рад

Универзитетска библиотека

UDK 342.738(497.11)

„Светозар Марковић”, Београд

brzulovic@unilib.rs

\title{
НОВО ДОБА ЗАШТИТЕ ПОДАТАКА О ЛИЧНОСТИ
}

Сажетак: Убрзани технолошки развој и глобализација доводе до појаве нових изазова у заштити података о личности. Интернет је преплављен мноштвом података и у сваком тренутку постоји латентна опасност од могућих злоупотреба путем појединих сајтова, социјалних мрежа, платформи. Треба пре свега истаћи да је право на заштиту података о личности у Србији зајемчено Уставом ${ }^{1}$ (што говори и о значају заштите овог права) и то Чл. 42 , који одређује да се прикупљање, држање, обрада и коришћење података о личности уређују законом. Забрањена је и кажњива употреба података о личности изван сврхе за коју су прикупљени, у складу са законом, осим за потребе вођења кривичног поступка или заштите безбедности Републике Србије, на начин предвиђен законом. Као последица процеса придруживања Републике Србије Европској унији, хармонизације права и директне примене права ЕУ, али и потребе, тј. недостатака старог законског решења, Србија је крајем 2018. године донела нови Закон о зашиичитии йоgайака o личносии $u^{2}$, с одложеним роком примене од девет месеци. У раду ћемо говорити

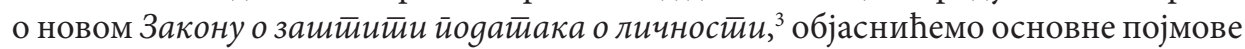
(податак о личности, врсте података, руковалац, обрађивач, обрада података, заштита података, пренос података, повереник, лице за заштиту података о личности) и новине које нам З3ПЛ доноси.

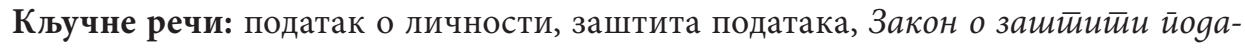

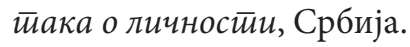

1 „Устав РС”, Службени іласник РС бр. 98 (2006), доступан на: https://www.paragraf.rs/propisi/ ustav_republike_srbije.html (приступљено 23.9. 2019).

2 „Закон о заштити података о личности”, Службени іласник РС бр. 87 (2018), доступан на: https://www.paragraf.rs/propisi/zakon-o-zastiti-podataka-o-licnosti.html (приступљено 29. 8. 2019).

3 У даљем тексту биће у употреби акроним 33Пл. 


\section{Увод}

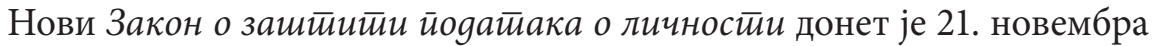
2018. године саодложеном применом од девет месеци. Тачније, 33ПЛ је почео да важи 21. августа 2019. године. Овај закон није новина у нашем законодавству јер се већ трећи пут доноси $(1998,2008)$. Према мишљењу стручњака из области права Закон има бројне недостатке, пре свега нејасне формулације и одредбе закона, као и преписане механизме који не постоје у домаћем законодавству, што доводи у питање његову примењивост ${ }^{4}$. Па, ипак и само нормативно 33ПЛ представља највиши стандард заштите података о личности. Према Члану 4, тачка 25. 33ПЛ се односи на државне органе, установе и друге јавне службе, организације и друга правна и физичка лица која имају јавна овлашћења. Прецизније речено, закон се примењује на све који обрађују податке о личности.

Новина у Закону је проширење обима важења и на промет робе и услуга на интернету. Закон треба тумачити заједно са ГДПР преамбулу и 173 тачке које нам помажу у разумевању целе приче. Примењује се територијално, руковалац и обрађивач морају бити са територије Србије. У неким ситуацијама овај се закон може примењивати и на стране компаније уколико је обрада података везана за понуду робе и услуга грађанима с територије Србије или ако је радња обраде везана за праћење активности лица на које се подаци односе, а активности се врше на територији Србије.

Основни циљ 33ПЛ је омогућити људима да поново поврате контролу над својим подацима (нови услови за пристанак на обраду података, нема бланко сагласности ). Нови Закон се не примењује када обраду врши физичко лице за своје личне потребе. На пример: лице које у бази свог телефона има лична имена и бројеве телефона, а које користи у приватне сврхе, нема обавезе према новом Закону. Затим, не примењује се ни на податке који су анонимни, односно на податке уз помоћ којих се не може

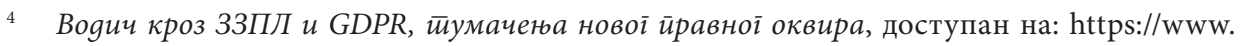
sharefoundation.info/Documents/vodic_zzpl_gdpr_share_2019.pdf.

5 General Data Protection Regulation, GDPR је скраћеница коју ћемо користити у овом тексту, будући да је у том облику већ у широкој употреби код нас. Интегрални текст европског прописа доступан је у преводу на хрватски језик, на адреси: https://eur-lex.europa.eu/legalcontent/HR/TXT/PDF/?uri=CELEX:32016R0679\&rid=1 (приступљено 16. 9. 2019). 
идентификовати лице (ни посредно, ни непосредно). Примена Закона се може избећи и онда када не постоји збирка података, односно подаци нису систематизовани и структурирани.

\section{Основни појмови}

Податак о личности ${ }^{6}$ је сваки податак који се односи на неко физичко лице, уз помоћ кога је идентитет тог физичког лица посредно или непосредно одређен или се може одредити. Идентитет лица може се одредити или идентификовати посредно или непосредно, посебно помоћу идентификатора као што су име, идентификациони број (JMBG), подаци о локацији, један или више фактора својствених за физички, физиолошки, генетски, ментални, економски, културни или друштвени идентитет тог физичког лица.

Ми овде не говоримо више само о имену и презимену, ЈМБГ-у, адреси и свему што нас директно идентификује. Мисли се на мноштво података преко којих се индиректно може доћи до неког лица. Ти подаци подразумевају велики број наших података на интернету (ИП адреса, ИМЕИ броја уређаја којим приступамо интернету, локација преко ГПС-а, шифре, налози електронске поште и налози на друштвеним мрежама итд.). Све набројано спада у податке о личности и ужива посебну заштиту.

Дакле, податак о личности се увек односи на физичко лице, никако на неки правни ентитет, али ако податак о неком правном лицу може довести до идентификације неког физичког лица, такав се податак сматра податком о личности (Тачка 27. Преамбуле ГДПР).

Под посебним подацима личности подразумевају се: расно или етничко порекло, политичко опредељење, верска или филозофска убеђења, припадност синдикату, генетски подаци, биометријски подаци, здравствено стање, сексуални живот или сексуална оријентација.

Обрада ових категорија података је начелно забрањена, с изузецима који су таксативно побројани у Закону, а уколико је испуњен неки од следећих услова:

- постоји изричит, добровољан и претходно дат пристанак лица чији се подаци обрађују,

6 Сви појмови су обрађени у Члану 4. 33ПЛ. 
- извршавање законских дужности и права руковаоца или лица на које се подаци односе у области права запошљавања и права социјалног осигурања и социјалне заштите,

- када лице није физички или правно способно да да̂ пристанак, а обрада је у његовом интересу,

- уколико обраду врши фондација, удружење и непрофитно тело, а односи се искључиво на чланове,

- обрада се односи на податке о личности за које је очигледно да их је објавило лице на које се подаци односе,

- обрада је неопходна за успостављање, остваривање или одбрану правних захтева пред судом,

- обрада у јавном интересу, уз обавезно поштовање мера безбедности и начела уредбе,

- обрада неопходна за потребе јавног здравља, превентивне медицине или медицине рада, медицинске дијагнозе, пружања здравствене или социјалне заштите, с тим што је руковалац обавезан да за обрађивача ангажује стручну особу, и

- архивирање у јавном интересу, потребе научног или историјског истраживања или статистичке потребе.

Иако З3ПЛ експлицитно не предвиђа да лице на које се подаци односе мора бити живо лице, наше је схватање да овај услов мора бити испуњен. ${ }^{7}$

Обрада података о личности је свака радња или скуп радњи које се врше аутоматизовано или неаутоматизовано с подацима о личности или њиховим скуповима. То су: прикупљање, чување, разврставање, увид, брисање, уништавање и похрањивање података.

Руковалац је физичко или правно лице, орган власти који самостално или заједно са другима одређује сврху и начин обраде података. Он одређује који ће се подаци прикупљати, о ком појединцу, како ће се чувати, да ли ће се и коме дистрибуирати подаци и колики је временски период чувања података.

Обрађивач је физичко или правно лице, орган власти који обрађује податке о личности у име руковаоца, а на основу уговора. Они самостално одлучују које ће методе користити за прикупљање података, како ће их похрањивати, старају се о њиховој безбедности, брину о средствима преноса података, као и начинима брисања података.

Воgич кроз З3ПЛ и GDPR, йумачеюа новоі̄ йравної оквира, доступан на: https://www. sharefoundation.info/Documents/vodic_zzpl_gdpr_share_2019.pdf. 
Прималац је физичко или правно лице, орган власти којем су подаци предочени.

Збирку података чини сваки структурисани скуп података о личности којем се може приступити или који се може претраживати по неком критеријуму. Дакле, да би се радило о збирци података у законском смислу, потребно је да су подаци систематизовано и структурно груписани на једном месту, било да су то фасцикле у орману, флеш меморија, диск, рачунар или нешто друго. Збирком података у смислу Закона не сматрају се лични адресари и фото-албуми ако их власник користи само у личне и непословне сврхе.

\section{Руковалац и обрађивач 8}

Руковалац је дужан да предузме одговарајуће техничке и организационе мере како би обезбедио да се обрада врши у складу с овим законом и био у могућности да то предочи, узимајући у обзир природу, обим, околности и сврху обраде, као и вероватноћу наступања ризика и ниво ризика за права и слободе физичких лица.

Руковалац је дужан да сталном применом одговарајућих техничких и организационих мера обезбеди да се увек обрађују само они подаци о личности који су неопходни за остваривање сваке појединачне сврхе обраде. Та се обавеза примењује у односу на број прикупљених података, обим њихове обраде, рок њиховог похрањивања и њихову доступност. Руковалац је дужан да води евиденцију о свим предузетим радњама током обраде (Члан 49. 33ПЛ).

Ако два или више руковаоца заједнички одређују сврху и начин обраде, они се сматрају заједничким руковаоцима. Своје деловање и поштовање одредаба Закона одређују споразумом. Заједнички руковаоци на транспарентан начин одређују одговорност сваког од њих за поштовање обавеза прописаних овим законом, а посебно обавеза у погледу остваривања права лица на које се подаци односе и испуњавања њихових обавеза да том лицу пруже информације.

Обрађивачи - физичка или правна лица која обрађују податке према писаним упутствима руковаоца (уговора о обради). Самостално одлучују које ће методе користити за прикупљање података, како ће их складишти-

8 Чланови 41-49. 33ПЛ. 
ти и брину о безбедности података, о средствима за пренос података о личности, као и о средствима за брисање и одлагање података. Они гарантују одговарајућу примену техничких и организационих мера приликом обраде података (Члан 43.33ПЛ).

И руковалац и обрађивач имају законску обавезу да сарађују са Повереником за информације од јавног значаја и заштиту података о личности (Члан 49. 33ПЛ). Уколико дође до повреде права лица чији се подаци обрађују, обрађивач одмах обавештава руковаоца. Руковалац обавештава Повереника (Члан 52. 33ПЛ) у року од 72 сата и лице на које се подаци односе (Члан 53. 33ПЛ). Руковаоц је дужан да документује повреду података о личности, чињенице о повреди и последице, и о предузетим мерама за њихово отклањање (Члан 52. 33ПЛ).

Заједничка обавеза руковаоца и обрађивача је да воде рачуна о безбедности података ${ }^{10}$ који се обрађују током трајања целог процеса. У том смислу препоручене мере заштите обухватају:

1) псеудонимизацију и криптозаштиту података о личности; ${ }^{11}$

2) способност обезбеђивања трајне поверљивости, интегритета, расположивости и отпорности система и услуга обраде;

3) обезбеђивање успостављања поновне расположивости и приступа подацима о личности у случају физичких или техничких инцидената у најкраћем року;

4) поступак редовног тестирања, оцењивања и процењивања делотворности техничких и организационих мера безбедности обраде.

Приликом процењивања одговарајућег нивоа безбедности посебно се узимају у обзир ризици обраде, а нарочито ризици од случајног или незаконитог уништења, губитка, измене, неовлашћеног откривања или приступа подацима о личности који су пренесени, похрањени или обрађивани на други начин. Руковалац и обрађивач дужни су да предузму мере у циљу обезбеђивања да свако физичко лице које је овлашћено за приступ подацима о личности од стране руковаоца или обрађивача обрађује ове податке само по налогу руковаоца или ако је на то обавезано законом.

Ако је вероватно да ће нека врста обраде, посебно употребом нових технологија и узимајући у обзир природу, обим, околности и сврху обраде, проузроковати висок ризик за права и слободе физичких лица, руковалац

\footnotetext{
У даљем тексу користиће се скраћени облик - Повереник.

Члан 50. З3ПЛ.

11 У самом 33ПЛ- $y$ није објашњен појам криптозаштите и Повереник је ставио примедбу на нацрт Закона.
} 
је дужан да пре него што започне с обрадом изврши процену утицаја ${ }^{12}$ предвиђених радњи обраде на заштиту података о личности. Приликом процене утицаја руковалац је дужан да затражи мишљење лица за заштиту података о личности, ако је оно одређено (Члан 55. 33ПЛ). Повереник је дужан да сачини листу радњи за које се захтева процена ризика.

\section{Начела обраде података ${ }^{13}$}

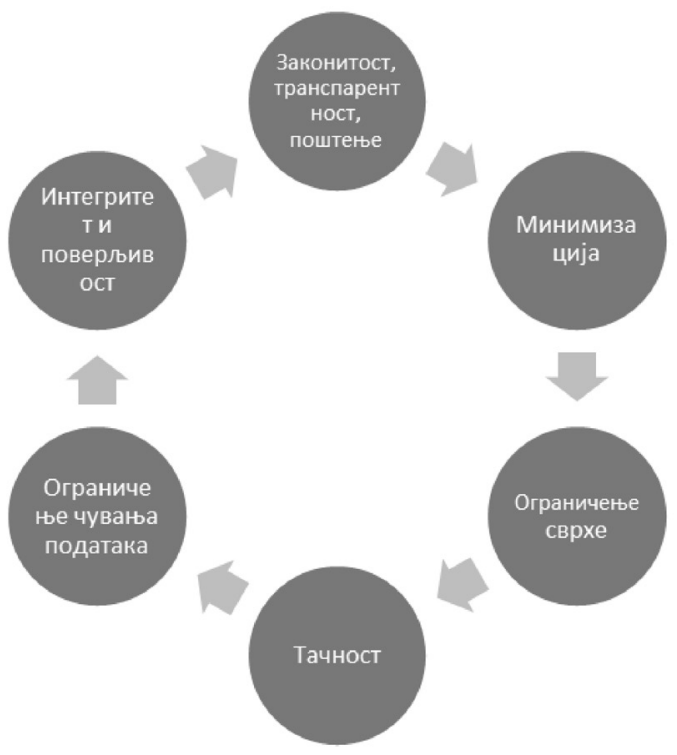

\section{Начело законитости}

Свака обрада података о личности мора да има јасно одређену, изричиту и оправдану сврху. Осим тога, сврха мора да буде законита. Шта то значи? Да би обрада била законита, неопходно је да се сврха обраде може подвести под један од шест законских правних основа. Обрада је законита уколико је:

1. лице чији се подаци прикупљају дало свој пристанак,

2. потребна за извршење уговора у којем је лице на које се подаци односе уговорна страна,

\footnotetext{
12 Члан 54. 33ПЛ.

13 Чланови 5-20. 33ПЛ.
} 
3. потребна за извршење законске обавезе која се примењује на руковаоца,

4. потребна ради заштите животно важних интереса лица на које се подаци односе или другог физичког лица,

5. потребна за извршење послова у јавном интересу,

6. потребна због легитимних интереса чијем остварењу тежи руковалац или треће лице.

Лице које је једном дало пристанак има право да га у сваком тренутку повуче на једнако једноставан начин као што је то прописано и за давање сагласности. Повлачење не утиче на законитост обраде извршене пре повлачења. За прикупљање и обраду података лица млађих од 16 година потребно је прибавити сагласност родитеља. Национална законодавства ову границу могу померити до тринаесте године. Карактеристично код прибављања сагласности родитеља је то што је закон, поред терета доказивања да је сагласност прибављена, обавезао руковаоца да учини све што је у његовој моћи да провери да ли је пристанак заиста дао родитељ, односно законски заступник детета.

\section{Начело сврсисходности}

Обрада је сврсисходна уколико се подаци о личности користе само за одређену сврху за коју је лице дало пристанак. Сврха мора бити изричита, конкретна, оправдана и законита. Уколико дође до промене сврхе приликом прикупљања података о личности, неопходна је нова сагласност лица чији се подаци обрађују.

\section{Начело транспарентности}

Деловање руковаоца мора бити законито, транспарентно и јасно према лицу чији се подаци користе. Лицу чији се подаци користе мора се јасно и недвосмислено рећи која су његова права у погледу заштите података о личности.

\section{Начело примерености и ограничености}

Подаци о личности могу се користити само у оном обиму који је неопходан да би се извршила обрада. Препорука је да обрађивачи прикупљају само неопходне податке, дакле минималне податке о личности.

\section{Начело тачности}

Подаци о личности морају бити тачни а лицу чији се подаци користе треба омогућити увид и могућност да укаже на нетачност, ажурирање или 
брисање података. Подаци који се користе у обради морају бити усклађени с евентуалним променама.

\section{Начело минимазације}

Подаци који се користе морају се минимизиовати, дакле само оно што је неопходно да би се испунила сврха обраде.

\section{Начело ограниченог времена обраде и чувања}

Подаци се чувају у што краћем временском року, не смеју се чувати дуже него што је неопходно у сврхе за које су прикупљени, а лице мора бити обавештено о дужини чувања његових података. Ово начело садржи у себи две компоненте:

1. Обавезу да се унапред одреди период чувања података у зависности од сврхе обраде.

2. Брисање и анонимизацију података ${ }^{14}$.

\section{Начело интегритета и безбедност}

Руковалац и обрађивач морају учинити све да се обезбеди безбедност података, укључујући и заштиту од неовлашћене и незаконите употребе података или евентуалног губитка.

\section{Права лица чији се подаци обрађују}

Закон осим начела обраде података о личости прописује и која су права лица чији се подаци обрађују.

\section{Право на информисаност ${ }^{15}$}

Руковалац предузима одговарајуће мере како би се лицу на које се подаци односе пружиле све информације и сва саопштења у вези с обрадом у сажетом, транспарентном, разумљивом и лако доступном облику, уз употребу јасног и једноставног језика, што се посебно односи на све информације које су изричито намењене детету. Руковалац на захтев пружа лицу на које се подаци односе информације о предузетим радњама без непотребног одлагања, а најкасније у року од месец дана од пријема захтева.

\footnotetext{
14 Анонимизација података је поступак обраде личних података којим се неповратно спречава идентификација појединца из обрађених података.

15 Члан 26. 33ПЛ.
} 


\section{Право на приступ и копију ${ }^{16}$}

Лице на које се подаци односе има право да добије потврду од руковаоца о томе да ли се обрађују његови подаци о личности и ако се такви подаци о личности обрађују, има право приступа и право на њихову копију. Информације се пружају у уобичајеном електронском облику,осим ако лице захтева другачије.

\section{Право на исправку ${ }^{17}$}

Лице на које се подаци односе има право да му руковалац без непотребног одлагања омогући исправку нетачних података о личности који се на њега односе. Узимајући у обзир сврху обраде, лице на које се подаци односе има право да допуни непотпуне податке о личности, између осталог давањем додатне изјаве.

\section{Право на заборав ${ }^{18}$}

Лице на које се подаци односе има право да му руковалац без непотребног одлагања омогући брисање података о личности који се на њега односе (и обрише податке код свих обрађивача или трећих лица код којих се налазе), ако је испуњен један од следећих услова:

- подаци о личности више нису неопходни за сврхе за које су прикупљени,

- лице на које се подаци односе је повукло сагласност и ако не постоји друга правна основа за обраду,

- лице на које се подаци односе је уложило приговор на обраду,

- подаци о личности су незаконито обрађени,

- подаци о личности морају да буду обрисани ради поступања у складу са законском обавезом према праву Уније или праву државе чланице које се примењује на руковаоца,

- подаци о личности су прикупљени у вези с понудом услуга информационог друштва лицу млађем од 16 година.

\section{Право на ограниченост обраде ${ }^{19}$}

Лице на које се подаци односе има право да захтева ограничење обраде од стране руковаоца ако је испуњен један од следећих услова:

\footnotetext{
16 Члан 26. 33Пл.

17 Члан 29. З3ПЛ.

18 Члан 30. З3ПЛ.

19 Члан 31. З3Пл.
} 
- лице на које се подаци односе оспорава тачност података о личности, у року који руковаоцу података омогућава да провери тачност података о личности,

- обрада је незаконита, а лице на које се подаци односе се противи брисању података о личности и уместо тога тражи ограничавање њихове употребе,

- руковаоцу података више нису потребни подаци о личности за потребе обраде, али их лице на које се подаци односе тражи због успостављања, остваривања или одбране правних захтева,

- лице на које се подаци односе је уложило приговор на обраду, а још није потврђено да ли легитимни разлози руковаоца преовлађују над разлозима лица на које се подаци односе,

- лице чији се подаци обрађују такође има право на исправку већ прикупљених података, као и право на заборав, односно на њихово брисање под одређеним условима.

\section{Право на преносивост података ${ }^{20}$}

Руковалац има право да (непосредно) преноси те податке другом руковаоцу података без ометања од стране руковаоца којем су подаци о личности пружени, ако:

- је обрада заснована на пристанку,

- се обрада врши аутоматски.

\section{Право на приговор ${ }^{21}$}

У било ком тренутку лице чији се подаци обрађују има право да уложи приговор, иако је претходно дало сагласност за обраду података. Руковалац је дужан да обустави даљу обраду података, осим ако не докаже легитимне разлоге за обраду. У случају приговора поводом коришћења у директном маркетингу, подаци се више не смеју користити. Независно од права на приговор надзорном органу, лицу чији се подаци обрађују у сваком случају је на располагању право на покретање судског поступка ради накнаде штете.

\footnotetext{
20 Члан 36. З3ПЛ.

21 Члан 37. 33ПЛ.
} 


\section{Надзорни орган}

Законодавац је кроз институцију надзорног органа са свим својим овлашћењима обезбедио јаку заштиту над подацима. А руковаоцима и обрађивачима је наметнуо обавезу информисања надзорног органа о свим питањима која се тичу кршења правила уредбе, нарочито злоупотребе и одлива података трећим лицима. Држање руковаоца у овим ситуацијама ће бити узимано у обзир приликом процене висине административних новчаних казни чије им плаћање може бити наметнуто.

\section{Лице за заштиту података}

Руковалац и обрађивач могу да одреде Лице за заштиту података о личности (Члан 56. 33ПЛ). Ако обраду података врше органи власти или у тој обради учествује већи број лица, онда су дужни да то ураде. Лице за заштиту података о личности је особа стручне квалификације, нарочито знања и искустава из области заштите података о личности у националном и међународном законодавству. Он је спона између организације која обрађује податке о личности и свих лица на која се ти подаци односе, у смислу информисања и остваривања законом гарантованих права. Повереник води листу лица за заштиту података о личности, а руковаоци или обрађивачи су дужни да обезбеде независност лица задужених за заштиту података о личности (Члан 57. 33ПЛ).

Делокруг послова Лица задуженог за заштиту података нарочито подразумева: активно учествовање у припреми општег акта о заштити података о личности, предлагање његових измена и допуна, као и одговорност за примену, контролу и предузимање мера у вези са заштитом, надзор над обрадом података, предлаже и покреће дисциплинске поступке у случају кршења закона односно уредбе, да брине о посебним мерама за заштиту података из категорије осетљивих, предлаже и предузима мере за обавештавање лица чији се подаци обрађују, води рачуна о неопходности, обиму и сврси обраде података, о времену чувања података и да се стара о поштовању начела минимализације, да обезбеђује доступност права лицима чији се подаци прикупљају и обрађују, обавештава лица о промени сврхе обраде и захтева додатне сагласности када је потребно, да обавештава лица и надзорни орган о проблемима безбедности или другом виду кршења правила закона и уредбе, у року предвиђеном оредбом, да 
води или организује регистар евиденција података, односно обраде, обезбеђује политику заштите података међу запосленима, едукује и обучава запослене у циљу што ефикасније примене правила уредбе и умањења могућности кршења, да прати регулативу и информише надлежне о новим правилима и потребама које се морају имплементирати у пословање и опште и појединачне акте, да извештава надлежне о стању података и мерама безбедности (Члан 58. 33ПЛ).

\section{Повереник за заштиту података од јавног значаја и заштиту података о личности}

1. Врши надзор и обезбеђује његову примену,

2. поступа по притужбама,

3. врши инспекцијски надзор над применом 33ПЛ- $a$,

4. израђује стандардне уговорне клаузуле,

5. сачињава и јавно објављује листе у вези с проценом утицаја,

6. води евиденцију лица за заштиту података о личности,

7. прописује и објављује критеријуме за акредитацију сертификационог тела,

8. има инспекцијска и друга овлашћења (33Пл Чланови 73-81).

\section{Казне}

Казне за непоштовање 33ПЛ- а у Србији су знатно ниже него у Европској унији. Новчана казна за руковаоца је од 50.000 до 2.000.000. динара. За више истовремених прекршаја руковалац може бити кажњен максималном казном од 4.000.000 динара. Поред казни које изричу Прекршајни суд и Повереник за информације од јавног значаја и заштиту података о личности може да казни руковаоца прекршајним налогом од 100.000 динара.

Повреда 33ПЛ- $a$ повлачи и кривичну одговорност уколико неко неовлашћено прикупља, складишти и дистрибуира податке о личности. Кривични законик Рейублике Србије предвиђа новчану казну и казну затвора до годину дана за неовлашћено прикупљање података о личности. На територији ЕУ казне изричу надлежни повереници у виду административних казни у износу од 20.000.000 евра или 4\% од глобалног годишњег прихода. 


\section{Практични кораци ка усаглашавању са 33ПЛ-ом}

Практични кораци:

1. евиденција свих података о личности који се прикупљају и обрађују,

2. утврдити политику приватности и заштите података о личности,

3. уграђена и подразумевана приватност,

4. подићи ниво безбедности - мере заштите података,

5. пренос података у друге државе,

6. припремити се за остваривање права лица о којима се прикупљају подаци,

7. обучити особље,

8. именовати лице за заштиту података о личности,

9. припремити интерна акта.

\section{Закључак}

Према досадашњим сазнањима везаним за сам 33ПЛ и његову примену, бар што се тиче библиотека у блиском окружењу и библиотеке у којој радим, није се одмакло даље од почетка. За већину институција сам Закон је непознаница а колеге често нису свесне да је заправо свакодневни посао у библиотекама везан за обраду неких података о личности. То практично значи да смо сви ми обрађивачи и да морамо обраду личних података да ускладимо са Законом. Неопходно је урадити мапирање података, утврдити степен поверљивости и осетљивости података, начин обраде и чувања података, увести систем привилегија (ко може приступити подацима) и извршити процену ризика. Наравно, следећи практични корак подразумева едукацију свих запослених и детаљне и писане инструкције везане за обраду података о личности. Осим тога, нужно је донети правилник којим прописујемо које податке о личности обрађујемо кад су у питању корисници библиотеке, а које у случају запослених. Колико ће тај процес трајати и колики је временски период у коме ћемо усаглашавати библиотечку делатност са Законом, у овом тренутку је немогуће предвидети. Свакако је пред нама врло напоран и тежак процес навикавања, учења и усаглашавања

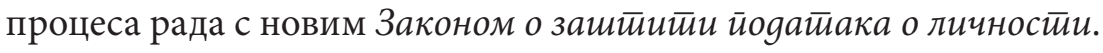




\section{Literatura:}

1. Direktiva EU 2016/680 o zaštiti pojedinaca u vezi s obradom podataka o kretanju, https://eur-lex.europa.eu/legalcontent/HR/TXT/?qid=1569498370383\&uri=CELEX:32016L0680.

2. Direktiva EU 95/46/EC o zaštiti podataka o ličnosti. eur-lex.europa.eu.

3. General Data Protection Regulation. https://eur-lex.europa.eu/legal-content/HR/ TXT/PDF/?uri=CELEX:32016R0679\&rid=1.

4. „Ustav Republike Srbije”. Službeni glasnik RS br. 98 (2006). https://www.paragraf. rs/propisi/ustav_republike_srbije.html. (na ćirilici)

5. Vodič kroz ZZPL i GDPR, tumačenja novog pravnog okvira. https://www.sharefoundation.info/Documents/vodic_zzpl_gdpr_share_2019.pdf.

6. „Zakon o zaštiti podataka o ličnosti”. Službeni glasnik RS br. 87 (2018), dostupan на: http://www.parlament.gov.rs/upload/archive/files/cir/pdf/zakoni/2018/2959-18. pdf. (na ćirilici) 


\title{
Tatjana Brzulović Stanisavljević
}

University Library "Svetozar Marković”, Belgrade

brzulovic@unilib.rs

\section{NEW AGE OF PERSONAL DATA PROTECTION}

\begin{abstract}
The intensive technological development and globalization are giving rise to new challenges in the protection of personal data. The internet is overflowing with information and at any moment there is a latent risk of possible misuse through particular websites, social networks, or platforms. It should be emphasized, first of all, that the right to protection of personal data in Serbia is guaranteed by the Constitution (which also indicates the importance of protecting this right) where Article 42 stipulates that collecting, holding, processing, and using of personal data are governed by law. The use of personal data outside the purpose for which they were collected in accordance with the law, except to conduct criminal proceedings or protect the security of the Republic of Serbia in the manner prescribed by law, is also prohibited. As a consequence of the process of accession of the Republic of Serbia to the European Union, the harmonization of legislation and the direct application of EU laws, but also because of the shortcomings of the old legal solution, Serbia adopted a new Law on Personal Data Protection at the end of 2018, with a delayed application period of nine months. This paper presents the new Law on Personal Data Protection, explains the basic concepts (personal data, types of data, controller, processor, data processing, data protection, data transfer, commissioner, data protection officer) and certain novelty elements brought by the Law on Personal Data Protection.
\end{abstract}

Keywords: personal data, data protection, Law on Personal Data Protection, Serbia.

Примљено: 25. септембра 2019.

Прихваћено: 21. октобра 2019. 